\section{BUTTERFLY PREDATION BY AN INSECTIVOROUS PLANT, DROSERA INDICA L.}

\author{
Md.Jafer Palot ${ }^{1}$ and K.M. Khaleel ${ }^{2}$ \\ ${ }^{1}$ Zoological Survey of India, Freshwater Biological Station, 1-1-300/ \\ B, Ashok Nagar, Hyderabad, Andhra Pradesh 500020, India. \\ ${ }^{2}$ Post Graduate Department of Botany, Sir Syed College, \\ Taliparamba, Kannur, Kerala 670142, India.
}

Insectivorous plants are usually found in habitats like barren open country, paddy fields and other marsh areas and as such are believed to supplement their diet with animal feed. Some insectivorous plants are found in extremely diverse environments while others are known to occupy narrow ecological niches. The insectivorous plants like Drosera indica L., $D$. burmanrii Vahl, D. peltata Smith and many species of the genus Utricularia are reported from Kerala. The traps of these plants are leaf (entire or part) or modified leaf-like organs to lure, guide, hold and digest the prey.

During our routine faunal observations and collections of plant material in the vicinity of Madayi Para, a flat-topped table like laterite hillock of Kannur District in northern Kerala, on $28 \mathrm{Au}$ gust 1999 , we came across exceptionally large numbers of Drosera indica plants in the south-western slope of the hill in association with other herbaceous plants such as Eriocaulon spp., Rhamphicarpa longiflora (Arn.) Benth., Sopubia delphinifolia (L.) G. Don, and another group of most common insectivorous plants of the area-Utricularia spp., which literally paint the whole plateau in shades of blue, violet and white with their flowers. Most of the Drosera plants were specked with small insect remains. On one plant at about a height of 10 cm., we found a female Pale Grass Blue Butterfly (Zizeeria maha) entangled in the sticky gland tipped tentacles of the plant. The antennae of the insect were stuck on the upper branches of the plant while the abdomen and part of the wings were just trapped in the lower branches of the plant. After a few minutes of struggle the butterfly was immobilized and the tentacle like leaves coiled towards the insect for the initiation of digestion process.

\section{Acknowledgements}

We are grateful to Dr. J.R.B. Alfred, Director, Zoological Survey of India, Calcutta and Dr. T. Muhamed, Principal, Sir Syed College, Taiparamba for facilities and encouragements.

Received 25 October 1999

Accepted 31 January 2000

\section{A SNAKE - PARAKEET INCIDENT}

\author{
Md. Jafer Palot, S.S. Kamble, S.V.A. Chandrasekhar and \\ V.P.Soniya
}

Freshwater Biological Station, Zoological Survey of India, 1-1-300/B, Ashoknagar, Hyderabad, Andhra Pradesh 500020, India.

During the course of hydrobiological studies of the wetlands of Keoladeo National Park, Bharatpur, Rajasthan, a bird-snake incident was observed, which is noteworthy.

On 17 April 1999 at $0945 \mathrm{hrs}$ while walking along a trail towards Sapanmori from Rambund in the park, the vociferous screaching and screaming of six Roseringed Parakeets ( Psittacula krameri borealis) attracted our attention. The birds were making alarm calls from a Babul tree (Acacia nilotica), which was leaning towards the marsh. At a height of about $10 \mathrm{ft}$. from the ground, the tree had a cavity in its trunk that was encircled by a heavybodied yellowish brown snake, with the rest of its body lying inside the cavity. Even though the first half of the anterior part of the approximately $2 \mathrm{~m}$. long snake could not be seen, it could be identified from the rest of its body which was elongated, cylindrical, ventral colouration dirty-yellow with black-tipped sides and from the long, slender tail, the scale pattern of the body, as a Rat Snake (Ptyas mucosus). This snake was the intruder into the hole-nest and the reason for the aggression of parakeets.

At times, the parakeets were agressively attacking the snake, but at no time during the period did the snake attempt to defend itself from the birds. When we approched the tree, most birds flew away to a nearby branch. But one male parakeet anxiously waited near the nest-hole. When the snake was disturbed by our presence, it moved further inside the cavity and disappeared deep into the tree trunk. According to Ali and Ripley (1983), the breededing seasobn of the parakeets is mainly from January to July. It is possible that the birds had a nest within the cavity.

\section{Acknowledgements}

The authors are grateful to Dr. J.R.B. Alfred, Director, ZSI; Dr. S.Z. Siddigi, Officer-in-Charge, Freshwater Biological Station, ZSI, Hyderabad and to Mrs. Shruthi Sharma, DCF, KNP.

\section{References}

Ali, S. and S.D. Ripley (1983). Hand Book of the Birds of India and pakistan (compact edition). Oxford University Press, New Delhi.

Received 8 November 1999 